\title{
Is the Murciano-Granadina a single goat breed? A molecular genetics approach
}

[É a Murciano-Granadina raça única? Um enfoque genético-molecular]

\author{
A.M. Martínez ${ }^{1}$, J.L. Vega-Pla ${ }^{2}$, J.M. León ${ }^{1}$, M.E. Camacho ${ }^{3}$, J.V. Delgado ${ }^{1}$, M.N. Ribeiro ${ }^{4,5^{*}}$ \\ ${ }^{1}$ Departamento de Genética - Universidad de Córdoba - Córdoba, España \\ ${ }^{2}$ Laboratorio de Investigación Aplicada - Servicio de Cría Caballar y Remonta - Córdoba, España \\ ${ }^{3}$ IFAPA - Centro Alameda del Obispo - Córdoba, España \\ ${ }^{4}$ Departamento de Zootecnia - UFRPE - Recife, PE \\ ${ }^{5}$ Bolsista do $\mathrm{CNPq}$
}

\begin{abstract}
The population structure of the Murciano-Granadina breed was determined using 25 microsatellites from 266 goats of seven populations. The results of the genetic differentiation analysis showed that it is possible to differentiate the Murciana and Granadina populations even though a low $\mathrm{F}_{\mathrm{ST}}$ value $(0.0432)$ had been obtained. Individuals could be assigned to their populations with a success rate of more than $80 \%$. Bayesian-based clustering analysis of allele frequencies and multivariate analysis revealed that Murciana and Granadina populations were grouped in different clusters since $K=3$. The results demonstrate that Murciana and Granadina are still two different genetic groups included into MurcianoGranadina denomination. There is the opportunity to the genetically manage these populations, under a single herd-book but adding the necessary modifications to respect the conservation of the genetic diversity based on the use of multibreed models of genetic evaluation.
\end{abstract}

Keywords: dairy goat, microsatellites, genetic diversity, conservation

\section{RESUMO}

Determinou-se a estrutura da raça Murciano-Granadina, usando-se 25 microssatélites e 266 animais de sete populações. Os resultados da diferenciação genética mostram que é possível diferenciar populações de Murciana e Granadina, apesar dos baixos valores de $F_{S T}$ obtidos - 0.0432. Os indivíduos foram designados às suas populações com taxa de sucesso superior a 80\%. A análise bayesiana de agrupamento das frequências alélicas e a análise multivariada revelaram que as populações Murciana e Granadina foram agrupadas em diferentes clusters, uma vez que o melhor $K$ obtido foi três. Os resultados demonstraram que Murciana e Granadina ainda são dois grupos genéticos distintos incluídos na denominação Murciano-Granadina. É possível manejar geneticamente essas populações dentro de um único livro de registro, porém adotando-se as modificações necessárias em relação à conservação e à diversidade genética, com base no uso de modelos de avaliação multirracial.

Palavras-chave: caprino leiteiro, microssatélites, diversidade genética, conservação

\section{INTRODUCTION}

Murciano-Granadina is an important goat breed in Spain, with more than 450,000 lactating females. This breed is one of the most important cosmopolitan dairy goats which also include Saanen, Alpine, Anglo-Nubian, and Toggemburg and has a relevant international importance because it have been exported to other countries of the Mediterranean Basin, Magreb, and LatinAmerica.

Recebido em 24 de novembro de 2009

Aceito em 2 de setembro de 2010

*Autor para correspondência (corresponding author)

E-mail:mn.ribeiro@uol.com.br 
In Spain, the country of origin of the MurcianoGranadina, there is a hard controversy about the genetic structure of this breed, mainly originated by the official consideration of the MurcianoGranadina as a single breed, after an official decision taken in the seventies. However, the breeders Associations defend the existence of two separate breeds based on historical hits.

The Granadina goat is known at least from the 15 th century, when the chronics mentioned it as one of the domestic populations implied in the colonization of the Spanish Latin-America (Rodero et al., 1992).

There are several references to both Granadina and Murciana breeds along the end of the 19th century and the beginning of the 20th (Sarazá, 1952). At those times, the genetic management of both breeds was separated but always keeping local interactions due to geographical contacts between both areas of distribution.

In the 60's and 70's of the 20th century, the search of genetic responses to selection in those breeds promoted the concentration of census. A single herd-book was created for the genetic management of Murciana and Granadina, in 1975 , stimulating the admixture of both original breeds during the last forty years. But, it is still unknown what the present genetic situation is, whether both original breeds still exist or a new synthetic breed has been created by the genetic management.

Microsatellites have shown its competitiveness for biodiversity studies. FAO and ISAG have recommended its use for the characterization of breeds and the establishment of genetic distances among them (FAO, 2004).

In goats, several studies have been developed using these tools (Barker et al., 2001; Luikart et al., 2001; Li et al., 2002; Xiang-Long and Valentini, 2004; Cañón et al., 2006; Martínez et al., 2006).

The goal of this work is to obtain genetic information on Murciano-Granadina breed based on microsatellite markers to determine population structure and the possible differentiation between original Murciana and Granadina populations, in order to decide breeding strategies to be taken in the future.

\section{MATERIAL AND METHODS}

Blood or hair root samples were randomly collected from herds belonging to different locations (no more than three samples per establishment). The sampling was distributed as follow according to previous morphological assignment (number of individuals in brackets): Murciana (40), Granadina (30), and MurcianoGranadina (40). Other national breeds as Blanca Andaluza (40), Blanca Celtibérica (40), Malagueña (40), and the international breed Saanen (36) were also sampled and used as comparative outgroup.

DNA was isolated from whole blood or hair root according to the methodology proposed by Walsh et al. (1991). Twenty-two microsatellites were amplified: BM6506, BM8125, BM1818, CSRD247, ETH225, HAUT27, ILSTS011, TGLA122, BM6526, CSRM60, ETH10, INRA6, MM12, HSC, McM527, SRCRSP8, OarFCB48, BM1329, OarFCB11, OarFCB304, MAF209, and MAF65, and PCR products were separated by electrophoresis in an automatic sequencer ABI 377XL (Applied Biosystems, Foster City, CA, USA). Sizing PCR products was accomplished both by the internal size standard and by the same reference sample in order to correct the few variations in allele size assignation among runs. Genetix v4.05 software (Belkhir et al., 2003) was used to calculate allele number as well as the observed and unbiased expected estimates of heterozygosity within breeds (Nei, 1973). Distribution of gene variability within and between breeds was studied by analysing Wright F-statistics (Weir and Cockerham, 1984) method. Deviations of genotype frequencies from Hardy-Weinberg equilibrium were studied using the exact tests based on a Markov chain method into Genepop v3.4 software (Raymond and Rousset, 1995). Reynolds genetic distance (Reynolds et al., 1983) was estimated using the Populations 1.2.28 (Langella, 1999) computer program. Distances between pairs of populations were used to build an UPGMA tree (Sneath and Sokal, 1973) and a Bootstrap resampling test $(n=1000)$ was performed to verify the dendrogram robustness. Factorial correspondence analysis (Lebart et al., 1984) was performed to test the possible admixtures that occurred between the populations by using the module "AFC sur populations" of the Genetix v4.05 software. 
Microsat v.1.5b computer program (Minch, 1998) was used to calculate pair wise distance values from inter-individual genetic distances, based on the proportion of alleles shared by two individuals averaged over loci (Bowcock et al., 1994). These distance values were used to construct a neighbour-joining tree using the Neighbor module of the Phylip v.3.57c computer package (Felsenstein, 1995).

A population assignment analysis was performed using the procedure proposed by Baudouin et al. (2004) and implemented in the Geneclass2 program (Piry et al., 2004). A Bayesian approach (Baudouin and Lebrun, 2001) was selected. This procedure assigns individuals to the population based on the highest likelihood to the individual genotype.

The structure v.2.1 software (Pritchard et al., 2000) was used to calculate clustering at different $\mathrm{K}$ values, that is, the number of assumed populations using the admixture model in which an individual may have mixed ancestry.
Runs of 600,000 iterations, were performed following a burn-in period of 200,000 iterations. In order to determine the adequate number of inferred clusters for fitting the data, K-values from 2 to 10 were evaluated as well three independent simulations were run to evaluate stability. Graphics from these results were drawn using Distruct software (http://rosenberglab.bioinformatics.med.umich.e $\mathrm{du} /$ distruct.htlm).

\section{RESULTS AND DISCUSSION}

All selected molecular markers showed high polymorphism (Table 1) with an average of 11.0 alleles per locus. High Fis values indicated that markers INRA63, SPS115, and CSSM66 have no neutral results (non amplified alleles, association with some selection character etc.).

Therefore, they were eliminated from the rest of the statistical analysis. A mean of 6.94 alleles per population was detected (Table 2).

Table 1. Number of alleles (NA), allele size, unbiased expected heterozygosity (He), observed heterozygosity (Ho), genetic differentiation index Fst, inbreeding coefficient Fis, and polymorphic information content (PIC)

\begin{tabular}{llllcccc}
\hline Locus & NA & Allele-size & He & Ho & Fst & Fis & PIC \\
\hline BM1329 & 10 & $150-190$ & 0.8010 & 0.7250 & 0.0480 & 0.0637 & 0.7746 \\
BM6506 & 11 & $190-230$ & 0.7719 & 0.7333 & 0.0468 & 0.0047 & 0.7433 \\
BM8125 & 8 & $100-130$ & 0.7200 & 0.7125 & 0.0348 & -0.0198 & 0.6917 \\
BM1818 & 11 & $250-290$ & 0.8265 & 0.7792 & 0.0324 & 0.0287 & 0.8023 \\
CSRD247 & 10 & $205-250$ & 0.7852 & 0.7208 & 0.0560 & 0.0417 & 0.7538 \\
HSC & 15 & $270-310$ & 0.8716 & 0.8102 & 0.0370 & 0.0401 & 0.8560 \\
MM12 & 18 & $85-135$ & 0.8862 & 0.8042 & 0.0603 & 0.0438 & 0.8743 \\
OarFCB48 & 10 & $140-170$ & 0.8613 & 0.7605 & 0.0291 & 0.0966 & 0.8432 \\
SRCRSP8 & 11 & $210-260$ & 0.6751 & 0.6167 & 0.0512 & 0.0540 & 0.6441 \\
MAF209 & 3 & $100-125$ & 0.2351 & 0.2208 & 0.0260 & 0.0322 & 0.2184 \\
HAUT27 & 7 & $125-160$ & 0.7582 & 0.7222 & 0.0514 & 0.0036 & 0.7191 \\
ILSTS011 & 10 & $250-295$ & 0.7266 & 0.6583 & 0.0229 & 0.0616 & 0.6893 \\
TGLA122 & 10 & $130-180$ & 0.7510 & 0.6008 & 0.0633 & 0.1550 & 0.7219 \\
BM6526 & 16 & $145-195$ & 0.7720 & 0.7042 & 0.0632 & 0.0332 & 0.7416 \\
INRA6 & 11 & $100-130$ & 0.8452 & 0.7593 & 0.0411 & 0.0748 & 0.8897 \\
McM527 & 9 & $150-190$ & 0.7015 & 0.6333 & 0.0762 & 0.0336 & 0.826 \\
OarFCB11 & 13 & $120-160$ & 0.8294 & 0.7406 & 0.0456 & 0.0709 & 0.6504 \\
OarFCB304 & 17 & $130-180$ & 0.7470 & 0.6250 & 0.0397 & 0.1329 & 0.8083 \\
MAF65 & 15 & $110-155$ & 0.8540 & 0.7815 & 0.0496 & 0.0408 & 0.7151 \\
CSRM60 & 7 & $75-110$ & 0.8121 & 0.7917 & 0.0072 & 0.0187 & 0.8365 \\
ETH225 & 6 & $130-165$ & 0.2081 & 0.2050 & 0.0246 & -0.0135 & 0.1991 \\
ETH10 & 5 & $200-230$ & 0.6029 & 0.6109 & 0.0318 & -0.0234 & 0.5233 \\
\hline & & & & & & &
\end{tabular}


Table 2. Sample size, number of alleles, unbiased expected heterozygosity $\left(\mathrm{H}_{\mathrm{z}}\right)$ or gene diversity, observed heterozygosity with its standard deviations (SD), inbreeding coefficient Fis with its confidence interval at $95 \%$, and percent of individual assignment to populations (IAP)

\begin{tabular}{|c|c|c|c|c|c|c|}
\hline Population* & $\begin{array}{l}\text { Sample } \\
\text { size }\end{array}$ & $\begin{array}{c}\text { Numbers } \\
\text { of alleles } \\
\text { (SD) }\end{array}$ & $\begin{array}{l}\text { Unbiased Hz } \\
\text { (SD) }\end{array}$ & $\begin{array}{c}\text { Observed } \mathrm{Hz} \\
\text { (SD) }\end{array}$ & $\begin{array}{c}\text { Fis } \\
\text { (CI 95\%) }\end{array}$ & $\begin{array}{l}\text { IAP } \\
(\%)\end{array}$ \\
\hline Murciana & 40 & $6.80(2.71)$ & $\begin{array}{c}0.6765 \\
(0.0336)\end{array}$ & $\begin{array}{c}0.6143 \\
(0.0165)\end{array}$ & $\begin{array}{c}0.0933 \\
(0.0270-0.1286)\end{array}$ & 85 \\
\hline $\begin{array}{l}\text { Murciana- } \\
\text { Granadina }\end{array}$ & 40 & $6.40(2.55)$ & $\begin{array}{c}0.6905 \\
(0.0345)\end{array}$ & $\begin{array}{c}0.6265 \\
(0.0218)\end{array}$ & $\begin{array}{c}0.0949 \\
(0.0067-0.1262)\end{array}$ & 35 \\
\hline Granadina & 30 & $7.32(2.69)$ & $\begin{array}{c}0.6961 \\
(0.0407)\end{array}$ & $\begin{array}{c}0.6635 \\
(0.0161)\end{array}$ & $\begin{array}{c}0.0475 \\
(-0.0069-0.0709)\end{array}$ & 80 \\
\hline $\begin{array}{l}\text { Blanca } \\
\text { Andaluza }\end{array}$ & 40 & $7.32(2.84)$ & $\begin{array}{c}0.6976 \\
(0.0351)\end{array}$ & $\begin{array}{c}0.6465 \\
(0.0154)\end{array}$ & $\begin{array}{c}0.0741 \\
(0.0284-0.0923)\end{array}$ & 88 \\
\hline $\begin{array}{l}\text { Blanca } \\
\text { Celtiberica }\end{array}$ & 40 & $7.96(3.31)$ & $\begin{array}{c}0.7026 \\
(0.0372)\end{array}$ & $\begin{array}{c}0.6487 \\
(0.0151)\end{array}$ & $\begin{array}{c}0.0776 \\
(0.0279-0.1007)\end{array}$ & 80 \\
\hline Malagueña & 40 & $7.36(3.00)$ & $\begin{array}{c}0.7120 \\
(0.0358)\end{array}$ & $\begin{array}{c}0.6371 \\
(0.0153)\end{array}$ & $\begin{array}{c}0.1066 \\
(0.0413-0.1458)\end{array}$ & 85 \\
\hline Saanen & 36 & $7.08(2.72)$ & $\begin{array}{c}0.6771 \\
(0.0431)\end{array}$ & $\begin{array}{c}0.6489 \\
(0.0163)\end{array}$ & $\begin{array}{c}0.0422 \\
(-0.0157-0.0669)\end{array}$ & 89 \\
\hline
\end{tabular}

All populations showed similar number of alleles and heterozygosities. Only the Granadina and the Saanen populations showed Fis values not significantly different from 0 . One locus was deviated from Hardy-Weinberg equilibrium in the Granadina population and two in the Murciana while the Muciano-Granadina population showed eight loci deviated.

The average F-statistics and their 95\% confidence intervals obtained with 10,000 bootstraps over loci were: Fis $=0.0761(0.0456$ $0.1166)$, Fit $=0.1160(0.0873-0.1548)$, and Fst $=$ 0.0432 (0.0367-0.0493). When the three studied populations (Murciana, Murciana-Granadina and Granadina) were considered separately, the Fstatistic values were: Fis $=0.0755 \quad(0.0393$ $0.1177)$, Fit $=0.1023(0.0673-0.1435)$ and Fst= 0.0289 (0.0184-0.0418).
A Bayesian approach (Baudouin and Lebrun, 2001) assigns individuals to the population having the highest likelihood to the individual genotype. The percentage of individuals correctly assigned (ICA) for all breeds are shown in Table 2. Only a 35\% of the MurcianoGranadina individuals were correctly assigned while $45 \%$ of them were assigned to Murciana population. Murciana and Granadina individuals showed an $80 \%$ of correct assignation ratio.

In order to compare these three populations with the other Spanish breeds geographically related with them, Reynolds distance (Reynolds et al., 1983) was estimated for each pair of populations (Table 3). The neighbour-joining tree built from Reynolds distances (Table 3) was rooted using the Saanen as out-group (Figure 1).

Table 3. Reynolds genetic distances estimated among seven goat populations

\begin{tabular}{|c|c|c|c|c|c|c|c|}
\hline & MUR & MG & GRAN & BLANCA & CELT & MALAG & SAAN \\
\hline MUR & & 0.0093 & 0.0426 & 0.0470 & 0.0468 & 0.0514 & 0.0833 \\
\hline MG & & & 0.0313 & 0.0477 & 0.0418 & 0.0484 & 0.0576 \\
\hline GRAN & & & & 0.0315 & 0.0312 & 0.0374 & 0.0655 \\
\hline BLANCA & & & & & 0.0286 & 0.0287 & 0.0685 \\
\hline CELT & & & & & & 0.0220 & 0.0642 \\
\hline MALAG & & & & & & & 0.0708 \\
\hline
\end{tabular}

Saanen breed was used as outgroup. MUR: Murciana; MG: Murciano-Granadina; GRA: Granadina; BLANCA: Blanca Andaluza; CELT: Blanca Celtibérica; MALAG: Malagueña; SAAN: Saanen. 


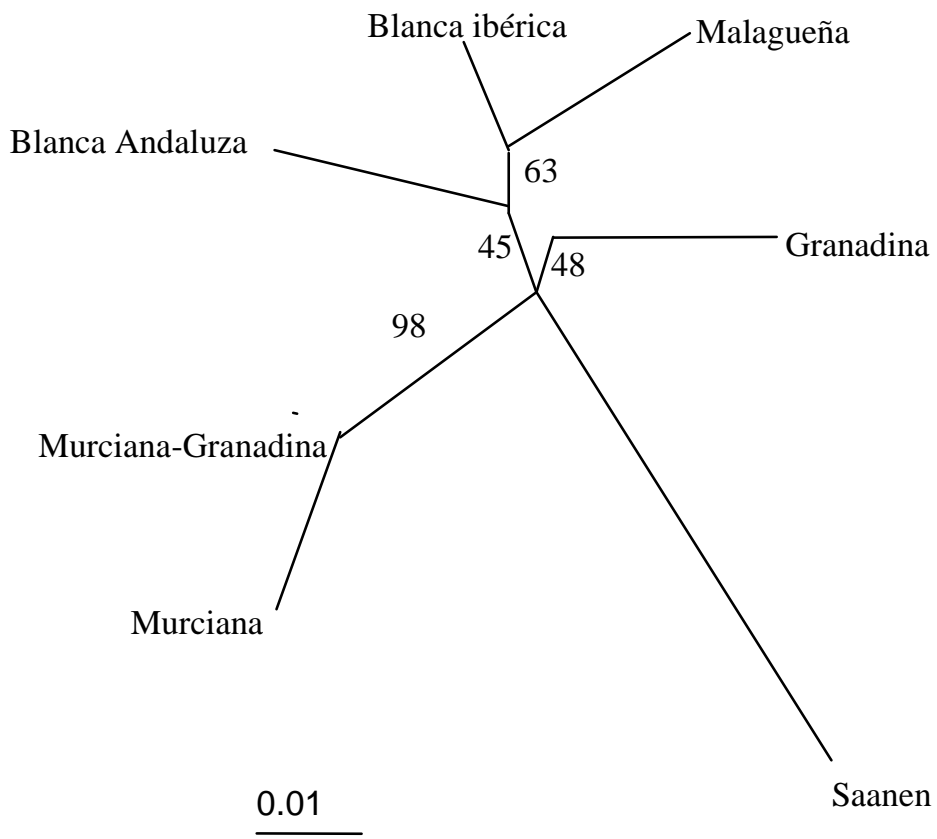

Figure 1. Neighbour-joining tree built from Reynolds distances of seven goat populations including a sample of Saanen goat to root the tree. Numbers indicate percentage of 1,000 bootstraps replications over loci.

The smallest distance found was between Murciana and Murciano-Granadina. Surprisingly, the population with the largest distance from Granadina population was

Murciana. Granadina was closer to the other Spanish breeds than to the Murciana population, and Murciano-Granadina cross is closely related to the Murciana population.

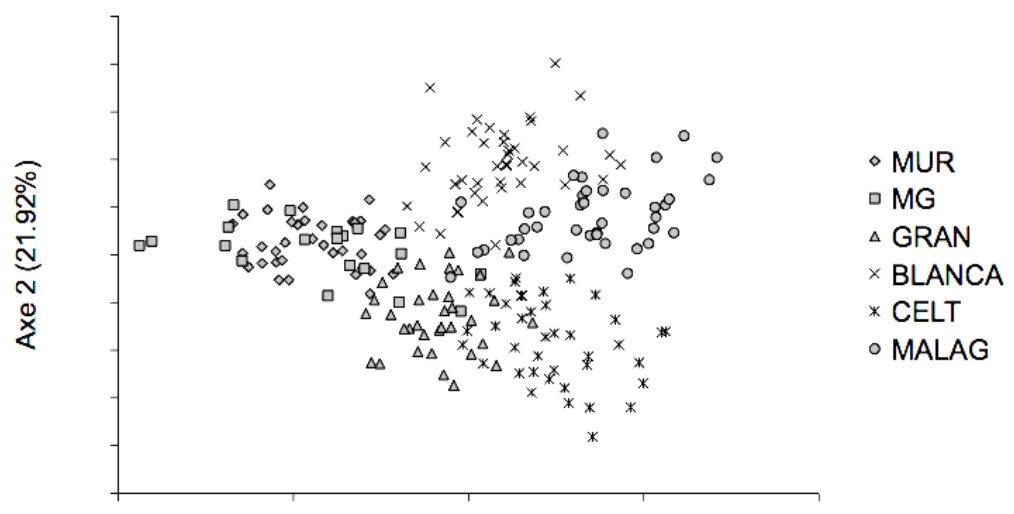

Axe $1(29.08 \%)$

MUR: Murciana; MG: Murciano-Granadina; GRA: Granadina; BLANCA: Blanca Andaluza; CELT: Blanca Celtibérica; MALAG: Malagueña; SAAN: Saanen.

Figure 2. Graphic representation of the factorial correspondence analysis of seven populations. Percentages of factors values are represented in the axis. 
The first axis accounted for $29.1 \%$ of the total inertia proportion, while the second axis accounted for $21.9 \%$, and the third $20.9 \%$ (not included in the graphic). Admixture can be appreciated between the Murciano-Granadina individuals and those pure belonging to Murciana population. These results remark the existence of genetic difference among the two investigated pure-bred goat populations, especially if the distances defined between them and the national and international outgroups introduced in the study are taken into account. The crossbreeding population was closer to the Murciana than to the Granadina population in both cases.
The structure program showed that the independent runs from $\mathrm{K}=2$ to $\mathrm{K}=7$ produced consistent results. Clustering was performed on the entire data set with increasing number of inferred clusters. The assignment test results (Figure 3) showed that from $K=3$ to $K=7$, the Murciana and Granadina pure populations form different clusters, and the Murciana-Granadina was in the same cluster as the Murciana for all the $\mathrm{K}$ values. Instead, the Granadina was differenciated from Murciana and MurcianoGranadina also for all K values.

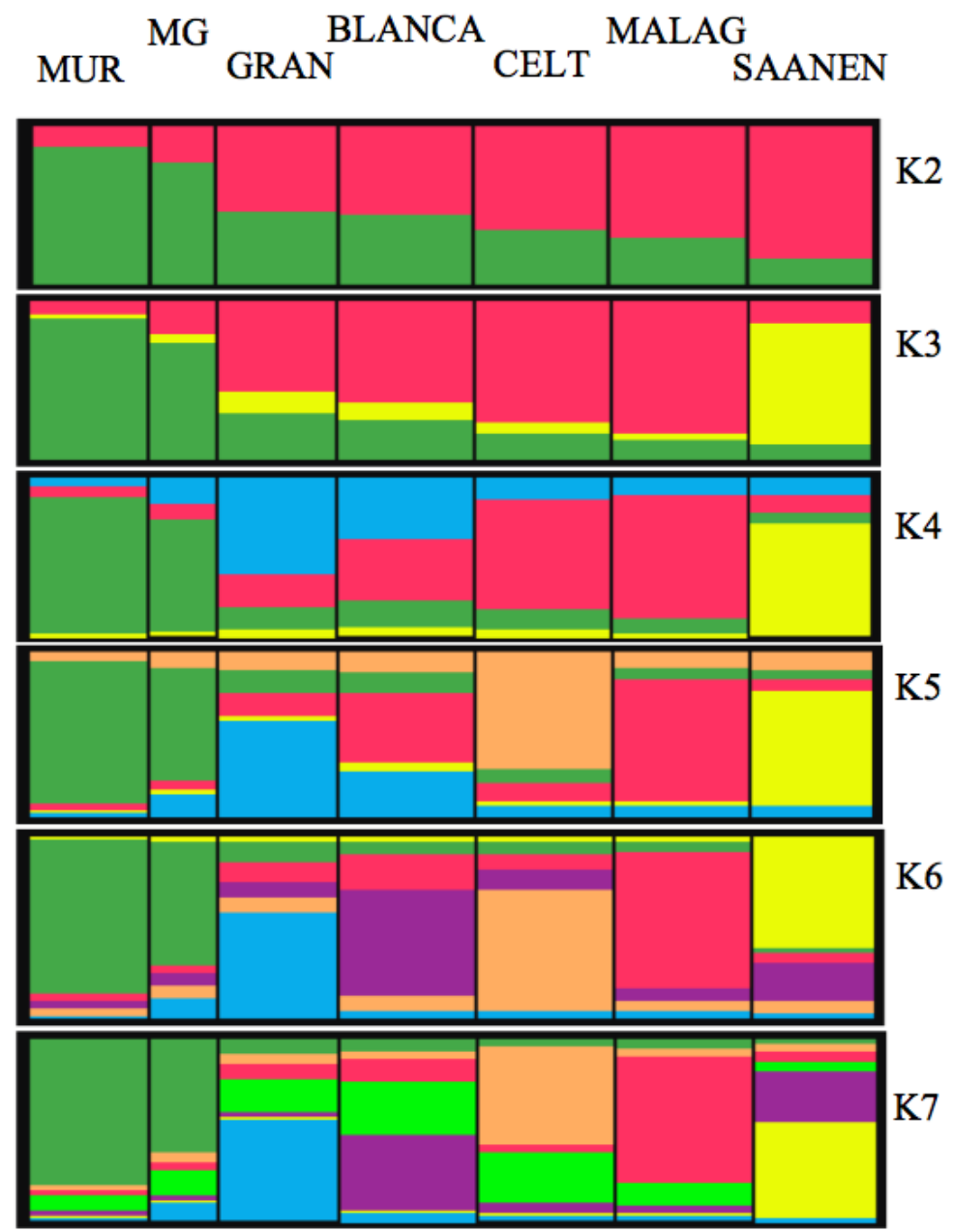

MUR: Murciana; MG: Murciano-Granadina; GRA: Granadina; BLANCA: Blanca Andaluza; CELT: Blanca Celtibérica; MALAG: Malagueña.

Figure 3. Estimated population structure of seven goat breeds for $\mathrm{K}=2-7$. Each population is represented by a stacked column broken into $\mathrm{K}$ different colour segments indicating the proportion of membership of each population to the $\mathrm{K}$ clusters. 
The panel of selected microsatellites showed very good effectiveness attending to the number of detected alleles, gene diversity, and $\mathrm{F}_{\text {IS }}$ values. The mean number of alleles was similar to those suggested by other authors as Jiménez-Gamero (2003) in Murciano-Granadina, Li et al. (2002) in Chinese local breeds, and Barker et al. (2001) in Asiatic goats. Cañón et al. (2006) also found a similar number of alleles in the Spanish breeds included in their research.

The three goat populations showed genetic diversity values above $65 \%$. The observed heterozygosity was higher than those observed by Saitbekova et al. (1999) in Swiss goat breeds and in Asiatic goats by Barker et al. (2001) and Xian-Long and Valentim (2004).

Mean Fis (0.76) was lower than the Fis value obtained in other goat breeds around the world (Barker et al., 2001; Xiang-Long and Valentini, 2004; Cañón et al., 2006) and higher than those found by Martínez et al. (2006). The Fis by population is lower than the values obtained by Cañón et al. (2006) in the Spanish breeds, except for Malagueña breed.

The Fst (0.04) was low compared with other domestic species (Hanslik et al., 2000; Martínez et al., 2000; Vega-Pla et al., 2006), and lower than those found in other studies in goat populations (Saitbekova et al., 1999; Barker et al., 2001; Li et al., 2002, Xiang-Long and Valentini, 2004; Cañón et al., 2006). The Fst in these goat populations was similar to the Fst found in other studies with Spanish goats (Martínez et al., 2006). The cause of these low values of Fst could be the phylogenetic proximity of the studied populations.

The poor detected genetic differentiation causes the low bootstrap values in the phylogenetic tree. This situation agrees with that found in other studies of goat populations (Barker et al., 2001; Li et al., 2002; Amills et al., 2004; Xiang-Long and Valentini, 2004).

The geographic distribution of these breeds, the South-East area of the Iberian Peninsula, makes possible the gene flow between them, at least before that the use of herd-books was established. Despite this present MurcianoGranadina crossbreeding when the seven populations are considered, it is not possible to distinguish between Murciano-Granadina and Murciana breeds, both in the Reynolds distance tree and the factorial correspondence analysis. Anyway, the distances found between both original populations are similar to those found between each of them and other breeds, such as Malagueña, Blanca Celtibérica, and Blanca Andaluza. Examination of population structure based on a clustering model (Pritchard et al., 2000) yielded the same results, not being possible to distinguish between MurcianoGranadina and Murciana breeds across K values.

The systematic effect of the consideration of Murciana and Granadina as a single breed has derived in the formation of a new synthetic population (Murciano-Granadina). This crossbreeding shows genetic stability according to the Hardy-Weinberg equilibrium and the results of the observed and expected heterozyigosits. The Murciano-Granadina breed is closer to Murciana than to Granadina due to the preferential use of Murciano reproducers. But the Granadina goat remains in South areas of Spain as genetic population.

\section{CONCLUSIONS}

These results support the hypothesis that Murciana and Granadina goats are still two different genetics groups included into Murciano-Granadina denomination. These populations are showing some levels of diversity from the seventies when the decision of fusion was taken. There is still the opportunity to the genetically manage these groups, under a single herd-book but adding the necessary modifications to respect the conservation of the genetic diversity based on the use of multibreed models of genetic evaluation.

\section{ACKNOWLEDGEMENTS}

We would like to acknowledge the submission of Murciana samples to Mr. Antonio Sanchez, ex-president of ACRIMUR. Our special acknowledgements to Mr. Javier Pleguezuelos, Mr. Rafael Villadén, Mr. Arturo Barroso, and all the National Association of Breeders of Goats of the Murciano-Granadina Breed (Granada, Spain) for their stimulus and financial support. Our thanks, as well to Cristina Gámez, Prof. of the University of Córdoba for her deep review of the language. 


\section{REFERENCES}

AMILLS, M.; CAPOTE, J.A.T.; KELLY, L. et al. Strong phylogoegraphic relationships among three goat breeds from the Canary Islands. J. Dairy Res., v.71, p.257-262, 2004.

BARKER, J.S.F.; TAN, S.G.; MOORE, S.S. et al. Genetic variation within and relatioships among populations of Asian goats. J. Anim. Breed. Gen., v.118, p.213-233, 2001.

BAUDOUIN, L.; LEBRUN, P. An operational bayesian approach for the identification of sexually reproduced crossfertilized populations using molecular marker. In: DORÉ, C.; DOSBA, F.; BARIL, C. (Eds). ISHS Acta Horticulturae 546 International symposium on molecular markers for characterizing genotypes and identifying cultivars in horticulture. Montpellier, France: ISHS, 2001. p.81-94.

BAUDOUIN, L.; PIRY, S.; CORNUET, J.M. Analytical bayesian approach for assigning individuals to populations. $J$ Hered., v.95, p.217-224, 2004

BELKHIR, K.; BORSA, P.; CHIKHI, L. et al. Genetix: 4.05 logiciel sous Windows TM pour la génétique des populations. Laboratoire Génome, Populations, Interactions, CNRS UMR 5000. Montpellier, France: Université de Montpellier II, 2003

BOWCOCK, A.M.; RUIZ-LINARES, A.; TOMFOHRDE, J. et al. High resolution of human evolution with polymorphic microsatellites. Nature, v.368, p.455-457, 1994.

CAÑÓN, J.; GARCÍA, D.; GARCÍA-ATANCE, M.A. et al Geographical partitioning of goat diversity in Europe and the Middle East. Anim. Genet., v.37. p.327-334, 2006.

FAO. Secondary guidelines for development of national farm animal genetic resources plans. Rome: FAO, 2004.

FELSENSTEIN, J. PHYLIP (Phylogeny Inference Package) version 3.5c. Distributed by the author. Seattle: Department of Genetics, University of Washington, 1993.

HANSLIK, S.; HARR, B.; BREM, G. et al. Microsatellite analysis reveals substantial genetic differentiation between contemporary New World and Old World Holstein Friesian populations. Anim. Genet., v.31, p.31-38, 2000

JIMÉNEZ-GAMERO, I.C. Clonación de microsatélites en la especie caprina y su aplicación a test de paternidad. Córdoba: University of Córdoba, 2003.

LANGELLA, O. Populations 1.2.28 (12/5/2002): population genetic software. CNRS UPR9034. Disponível em: <http://www.pge.cnrsgif.fr/bioinfo/populations/index.php, 1999>. Acessado em: 24 ago 2009.

LEBART, L.; MORINEAU, A.; WARWICK, K. Multivariant descriptive statistical analysis. New York: John Wiley and Sons, 1984. 231p

LI, M.; ZHAO, S.; BIAN, C. et al. Genetic relationships among twelve Chinese indigenous goat populations based on microsatellite analysis. Genet. Sel. Evol., v.34, p.729-744, 2002

LUIKART, G.; GIELLY, L.; EXCOFFIER, L. et al. Multiple maternal origins and weak phylogeographic structure in domestic goats. Proc. Natl. Acad. Sci. USA, v.98, p.59275932, 2001.
MARTÍNEZ, A.M.; ACOSTA, J.; VEGA-PLA, J.L. et al. Analysis of the genetic structure of the canary goat populations using microsatellites. Liv. Sci., v.102, p.140-145, 2006

MARTÍNEZ, A.M.; DELGADO, J.V.; RODERO, A. et al. Genetic structure of the Iberian pig breed using microsatellites. Anim. Genet., v.31, p.295-301, 2000.

MINCH, E. 1998. MICROSAT Version 1.5b Macintosh. Palo Alto: University of Standford, 1998.

NEI, M. Analysis of gene diversity in subdivided populations. Proc. Natl. Acad. Sci. USA, v.70, p.3321-3323, 1973.

PIRY, S.; ALAPETITE, A.; CORNUET, J.-M. et al. GeneClass2: a software for genetic assignment and first generation migrants detection. J. Hered., v.95, p.536-539, 2004

PRITCHARD, J.K.; STEPHENS, M.; DONNELLY, P. Inference of population structure using moltilocus genotype data. Genetics, v.155, p.945-949, 2000

RAYMOND, M.; ROUSSET, F. GENEPOP Version 1.2.: Population genetics software for exact test and ecumenicism. J. Hered., v.863, p.248-249, 1995

REYNOLDS, J.; WEIR, B.S.; COCKERHAM, C.C. Estimation of the coancestry coefficient basis for a short-term genetic distance. Genetics, v.105, p.767-779, 1983.

RODERO, A.; DELGADO, J.V.; RODERO, E. Primitive andalusian livestock an their implications in the discovery of America. Arch. Zootec., v.41, p.383-400, 1992

SAITBEKOBA, N., GAILLARD, C., OBEXER-RUFF, G. et al. Genetic diversity in Swiss goat breeds based on microsatellite analysis. Anim. Genet., v.30, p.36-41, 1999.

SARAZÁ, R. Raza caprina granadina. Córdoba: Imprenta Moderna, 1952. 128p

SNEATH, P.H.A.; SOKAL, H.H. Numerical taxomomy. San Francisco: Freeman, 1973

VEGA-PLA, J.L.; CALDERÓN, J.; RODRÍGUEZGALLARDO, P.P. et al. Saving feral horse populations: does it really matter? A case study of wild horses from Doñana National Park in southern Spain. Anim. Genet., v.37, p.571578, 2006.

WALSH, P.S.; METZGER, D.A.; HIGUCHI, R. Chelex 100 as a medium for simple extraction of DNA for PCR-based typing from forensic material. Biotechniques, v.10, p.506$513,1991$.

WEIR, B.S.; COCKERHAM, C.C. Estimating F statistics for the analysis of population structure. Evolution, v.38, p.13581370,1984

XIANG-LONG, L.; VALENTINI, A. Genetic diversity of Chinese indigenous goat breeds based on microsatellite markers. J. Anim. Breed. Genet., v.121, p.350-355, 2004 